\title{
ANTECEDENTS OF CONSUMER-BASED ELECTRONIC RETAIL BRAND EQUITY: AN INTEGRATED MODEL
}

\author{
Muhammad Mohsin Butt ${ }^{1 *}$, Yu Yingchen², Amrul Asraf Mohd-Any ${ }^{3}$, \\ Dilip S. Mutum ${ }^{4}$, Hiram Ting ${ }^{5}$, and Khong Kok Wei ${ }^{6}$
}

${ }^{1}$ Department of Management, Ghulam Ishaq Khan Institute of Engineering Sciences and Technology, Topi, Swabi, Khyber Pakhtunkhwa 23640, Pakistan

${ }^{2} J J L$ Overseas Education Consulting \& Service Co. Ltd., Beijing 100022, China

${ }^{3}$ Department of Marketing, Faculty of Business and Accountancy, University of Malaya, 50603 Kuala Lumpur, Malaysia

${ }^{4}$ Nottingham University Business School, University of Nottingham Malaysia Campus, 43500 Semenyih, Selangor, Malaysia

${ }^{5}$ Faculty of Hospitality and Tourism Management, UCSI University Kuching Campus, 93450 Kuching, Sarawak, Malaysia

${ }^{6}$ The Faculty of Arts and Social Sciences, University of Nottingham Malaysia Campus, 43500 Semenyih, Selangor, Malaysia

*Corresponding author: mohsinbutt@hotmail.com

Published online: 21 December 2018

To cite this article: Butt, M.M., Yu, Y., Mohd-Any, A.A., Mutum, D.S., Ting, H., and Khong, K.W. (2018). Antecedents of consumer-based electronic retail brand equity: An integrated model. Asian Academy of Management Journal, 23(2), 69-99. https://doi.org/ 10.21315/aamj2018.23.2.4

To link to this article: https://doi.org/10.21315/aamj2018.23.2.4

\begin{abstract}
The purpose of this study is to test and compare multiple conceptual models that examine the relationships among electronic retail (e-retail) service quality, trust, satisfaction, and consumer-based e-retail brand equity. A quantitative survey was conducted among Chinese online shoppers. The survey used established scales to measure constructs in the proposed models. Structural equation modelling (SEM) procedure was applied to test alternate models. The results confirmed that web design and customer service positively influence satisfaction, while fulfilment and security dimension of e-retail quality influence consumer trust. Both trust and satisfaction were found to be significant influencers of consumer-based e-retail brand equity. E-retailers can use this model to measure, monitor, and improve their consumer's perceptions towards their brand. This study contributes to
\end{abstract}

(C) Asian Academy of Management and Penerbit Universiti Sains Malaysia, 2018. This work is licensed under the terms of the Creative Commons Attribution (CC BY) (http://creativecommons. org/licenses/by/4.0/). 
the existing literature that deals with antecedents of online consumer-based retail brand equity. It adds value by proposing and testing multiple models of online consumer-based brand equity which is rare in e-brand equity research.

Keywords: online retail brand equity, e-trust, e-satisfaction, e-retail service quality, brand equity

\section{INTRODUCTION}

Online retailer brand equity is the differential effect of consumers' knowledge of an online store brand based on their personal experience, word of mouth and/ or exposure to the marketing activities of a brand (Hartman \& Spiro, 2005). For online retailers, the management of their retail brand equity is essential to maintain a sustainable competitive advantage (Christodoulides, de Chernatony, Furrer, Shiu, \& Abimbola, 2006; Kim, Sharma, \& Setzekorn, 2002; Kotha, Rajgopal, \& Rindova, 2001). Past studies suggest that online retailers can build stronger consumer-based brand equity by providing excellent service quality, building consumer trust on their brands, and meeting their expectations (Loureiro, 2013; McKinney, Yoon, \& Zahedi, 2002; Porter, 1980).

Despite the strategic importance for e-retailers to create, nurture, and manage their consumer-based retail brand equity, research in this area focus more on the electronic retail or e-retail quality rather than e-retail brand equity. Furthermore, limited attempts were made when it comes to connecting e-retail quality dimensions with consumer online relationship preferences in shape of trust, value, satisfaction, and brand equity (Esch, Langner, Schmitt, \& Geus, 2006; He \& Li, 2010; Kim, Jin, \& Swinney, 2009; Rios \& Riquelme, 2010; Subramanian, Gunasekaran, Yu, Cheng, \& Ning, 2014). For example, a meta-analytic literature review of online service quality did not identify overall brand equity or any of its dimensions as one of the significant outcome variable (Blut, Chowdhry, Mittal, \& Brock, 2015). Similarly, a recent review of the sources of online brand equity suggest that there are few studies which explicitly conceptualised and empirically tested the antecedents of consumer-based brand equity in an online context (Rana, Bhat, \& Rani, 2015).

As the online branding is still in its formative stage, studies investigating the antecedents or consequences of online brand equity are riddled with widely different conceptualisations and measurement (Anselmsson, Burt, \& Tunca, 2017; Bilgihan, 2016; Kao \& Lin, 2016; Keller, 2016; Londoño, Elms, \& Davies, 2016; Rowley, 2009; Yadav \& Pavlou, 2014). For example, Rios and Riquelme (2008) 
initially proposed awareness, trust, value, and loyalty as the antecedents of online brand equity. In their subsequent research they offered a much wider conceptual model by incorporating the multidimensional e-service quality construct as the antecedent of trust, value, and loyalty (Rios \& Riquelme, 2010). Kao and Lin (2016) tested the influence of online delivery and outcome service quality dimensions on e-brand equity mediated through trust, satisfaction, and loyalty. Others have used a first order/overall service quality construct to explore the direct or indirect relationship between e-service quality and e-brand equity (Chang \& Wang, 2011; Londoño et al., 2016). Some opted to relate e-service quality with consumer online loyalty which is considered as one of the dimension of brand equity (Çifci et al., 2016; Cristobal, Flavián, \& Guinaliu, 2007; Kim et al., 2009; Park \& Kim, 2003), while others considered overall service quality as the direct antecedent and loyalty as the outcome of e-retail brand equity (Bilgihan, 2016; Londoño et al., 2016; Swoboda, Weindel, \& Hälsig, 2016).

These wide and distinct conceptualisations in existing online brand equity research highlight the need to synthesise and summarise the existing research into a brief, more logical, theory driven, and integrated model. Therefore, the key objective of this research is to propose a model of consumer-based brand equity by synthesising and summarising the existing research on consumer-based e-retail brand equity. Based on the existing limited research, one can infer that e-retail service quality, trust, satisfaction, value, and loyalty are some of the most important predictors of overall consumer-based online brand equity (Rana et al., 2015).

Based on prior research, our model proposes (see Figure 1) that security and reliability/fulfilment dimension of e-retail quality influence consumer-based e-retail brand equity through trust. Similarly, website design and customer service indirectly influence e-retail brand equity through customer satisfaction (Alam \& Yasin, 2010; Cai \& Xu, 2006; Cyr, 2008; He \& Li, 2010; Kim et al., 2009; Reichheld, Markey, \& Hopton, 2000; Rios \& Riquelme, 2010; Singh \& Sirdeshmukh, 2000). Furthermore, we tested two additional models. The first alternative model tests the direct relationship between individual dimensions of e-retail quality and overall brand equity (Yoo, Donthu, \& Lee, 2000); this approach is rarely used in the e-retail brand equity literature (Londoño et al., 2016). The second alternative model uses each dimension of the e-retailing quality scale as an observed variable to create the first order overall service quality construct, which influence e-retail brand equity through consumers' online trust and satisfaction.

From a contextual point of view, this research investigates consumers' perceptions towards e-retail brands. Recent literature reports that e-channels are growing at an exceptional rate in emerging as well as in developed economies (Blut et al., 2015). 
This study centres on China as it has the fastest growing and largest e-commerce sector in the world (Atsmon, Dixit, Magni, \& St-Maurice, 2010). It is growing at a phenomenal rate of $75 \%$ annually as compared to the global average growth rate of $15 \%$ to $20 \%$. E-commerce roughly contributes around USD 1 trillion to the Chinese retail sector and is around $17.3 \%$ of its total retail sector (Goodman Report, 2012; FinancialBuzz.com, 2018; Subramanian et al., 2014). However, despite its strategic importance, there has been negligible research looking at the perceptions and preferences of Chinese consumers towards e-retail brands.

This paper is organised as follows. First, it starts with a review of the extant literature, followed by hypotheses development. Sampling, data collection techniques, and measurement of variables are discussed in the methodology and measurement section. Then, the results of the structural equation modelling (SEM) are presented, along with a brief commentary. Finally, conclusions, limitations, and implications are discussed.

\section{LITERATURE REVIEW AND CONCEPTUAL MODEL}

\section{Electronic Service Quality}

Past studies have investigated electronic service quality from multiple perspectives. Some linked it to the quality of a website (Sun, Cárdenas, \& Harrill, 2016; Yoo \& Donthu, 2001), while others were more focused on customer overall perceptions and experience of using a website (Barnes \& Vidgen, 2002; Nguyen, de Leeuw, \& Dullaert, 2018; Zeithaml, Parasuraman, \& Malhotra, 2002). E-service quality is defined as the consumers' overall evaluation and judgement of the excellence of service offerings in an online context (Santos, 2003). In contrast, Zeithaml et al. (2002) suggest that the term "e-service quality" refers to the extent to which a website provides its customer an efficient and effective mechanism to have an excellent shopping experience. This view was further supported by Piercy (2014), who defined online service quality as a process that encompasses "pre purchase, purchase and post purchase activities involving evaluation, selection, purchase and fulfilment of products and services through a website" (Shi et al., 2018, p. 748).

As the context of this research is focused on online retail branding, the definition developed by Wolfinbarger and Gilly (2003) is most suitable. They conceptualised that internet shopping experiences encompass the entire process, starting from information search, website navigation, ordering, customer services interaction, payment procedure, delivery, and after sales support. They proposed a four- 
dimensional e-retail quality scale to measure shoppers' perception of online retail quality, which consisted of (1) website design, (2) fulfilment and reliability, (3) security and privacy, and (4) customer service.

Website design deals with the consumer's interaction with the website, such as navigation, information search, ordering processing, and product selection (Wolfinbarger \& Gilly, 2003). Website design is an important source of creating a favourable first impression in the consumer's mind (Kim et al., 2009). This first impression serves as a building block for customer's satisfaction with the online retailer. Past research defined consumer online satisfaction as "the contentment of the customer with respect to his or her prior purchasing experience with a given electronic commerce firm" (Anderson \& Srinivasan, 2003, p. 125). An effective website design helps and facilitates a seamless consumer experience to navigate, search, select, and order their desired product and enhance their overall satisfaction (Devaraj, Fan, \& Kohli, 2002; Kim et al., 2009; Shankar, Urban, \& Sultan, 2002; Szymanski \& Hise, 2000; Zeithaml et al., 2002). On the other hand, a poor web design can create irritation resulting into consumer dissatisfaction (Hasan, 2016).

Several past studies provide empirical evidence that effective and efficient website design facilitates the speed of ordering and transaction, and enhances customer satisfaction towards a website (Alam \& Yasin, 2010; Cai \& Xu, 2006; Cyr, 2008; Park \& Kim, 2003). Therefore, the following hypothesis is postulated:

H1: Website design has a positive impact on consumers' online satisfaction.

In context of online retailing, customer service (also referred to as responsiveness) is a dimension of e-retail quality reflecting an online retailer's willingness and ability to respond and help towards customer enquiries and complaints (Wolfinbarger \& Gilly, 2003). Online customers usually expect a prompt response to their inquiries and concerns (Liao \& Cheung, 2002; Gummerus, Liljander, Pura, \& van Riel, 2004; Liu, He, Gao, \& Xie, 2008). Organisational abilities and efforts to promptly respond to customers inquiries/complaints result into more satisfied customers (Cao, Ajjan, \& Hong, 2018; Devaraj et al., 2002; Jain, Gajjar, Shah, \& Sadh, 2017; Kim \& Stoel, 2004). Others have found no significant effect of quality of customer service on customer satisfaction (Kim et al., 2009; Kassim \& Abdullah, 2010). These contradicting results merit further investigations. Therefore, this study proposes the following hypothesis:

H2: Customer service has a positive impact on consumers' online satisfaction. 
Online shoppers are most concerned about the privacy and security of their personal and financial information (Devaraj et al., 2002; Liu \& Arnett, 2000; Wolfinbarger $\&$ Gilly, 2003). The security and privacy dimension of e-retail service quality includes the security of customer credit/debit card details and protection of personal information that a customer needs to share to complete his/her online purchasing (Agag, El-Masry, Alharbi, \& Ahmed Almamy, 2016; Wolfinbarger \& Gilly, 2003). Security and privacy are regarded as one of the key criteria on which a consumer assesses the trustworthiness of an online organisation (Aiken \& Bousch, 2006; Hoffman, Novak, \& Peralta, 1999). Several previous studies reported a strong relationship between consumer perception of organisational ability to maintain security and privacy of their data and their trust in that organisation (Kim et al., 2009; Park \& Kim, 2003; Ribbink, van Riel, Liljander, \& Streukens, 2004; Szymanski \& Hise, 2000). Past research also reported negative relationships between consumer perceptions of lack of integrity, security, and reliability of website and his/her perceptions of trustworthiness of a website (Oliveira, Alhinho, Rita, \& Dhillon, 2017). Furthermore, a recent meta-analysis study conducted by Kim and Peterson (2017) report that perceived security as well as privacy are some of the strongest predictors of consumer online trust with a website. In line with the conceptualisation by Kim et al. (2009), we also propose that security and privacy dimension of e-retail quality will directly influence consumer e-trust and indirectly influence consumer online satisfaction through e-trust.

H3: Security/privacy has a positive impact on consumers' trust towards the online business.

Past research defined fulfilment as a multidimensional construct reflected by timeliness, availability, conditions, and billing accuracy (Koufteros, Droge, Heim, Massad, \& Vickery, 2014; Mentzer, Gomes, \& Krapfel, 1989). The fulfilment and reliability aspect of e-retail quality deals with firms' ability to provide accurate product and process specific information followed by delivery of purchased items within the promised time frame (Wolfinbarger \& Gilly, 2003). Any breach of promise from the e-retailer, such as wrong product delivery or a complete/partial failure to deliver products on time, usually results in consumer distrust towards that retailer. Several past studies reported a positive relationship between accurate order fulfilment and consumer trust towards online retailer (Reichheld et al., 2000; Singh \& Sirdeshmukh, 2000; Kim et al., 2009). Hence, this paper hypothesises that fulfilment will positively influence trust in the online retailing context:

H4: Accurate fulfilment/reliability has a positive impact on consumers' trust towards the online business. 


\section{Online Trust and Customer Online Satisfaction}

Trust is "the willingness of the party to be vulnerable to the actions of another party based on the expectation that the other will perform a particular action important to the former, irrespective of his ability to monitor or control the later" (Mayer, Davis, \& Schoorman, 1995, p. 712). In an online context, trust reflects an individual/organisation's attitude of confidence towards a retailer that it will not exploit their vulnerabilities (Corritore, Kracher, \& Wiedenbeck, 2003). Online trust can be distinguished from offline trust on the ground that the object of trust moves from employees and product brand to the e-retailing brand (Beldad, de Jong, \& Steehouder, 2010; Shankar et al., 2002). In other words, trust in the online context is fundamentally different from offline context due to the fact that it is built on a person-to-website basis rather than a person-to-person basis (Hongyoun Hahn \& Kim, 2009; Winch \& Joyce, 2006).

In an online environment, it is not surprising to note that online trust or e-trust continues to be one of the main concerns for customers (Tamimi, Rajan, \& Sebastianelli, 2003). E-trust is important for consumers due to several reasons. First, they are not able to personally scrutinise the vendor, second, they cannot physically experience the product, and finally they will not be able to immediately collect their merchandise upon payment (Fang, Chiu, \& Wang, 2011). Consumers' scepticism towards online brand stems from the common perception of high risk associated with online shopping and their inability to gather sufficient information to make a credibility judgement about an online vendor (Anderson \& Srinivasan, 2003; Grabner-Kraeuter, 2002; Kim et al., 2002). As a result, a substantial number of studies found that lack of trust is the biggest barrier for consumers' willingness to shop online (Hoffman et al., 1999; Lee \& Turban, 2001; McKnight, Choudhury, \& Kacmar, 2002; Pavlou, Liang, \& Xue, 2007). Furthermore, trustworthiness of the intermediary brand plays a critical role in determining the extent to which consumers trust the online marketplace (Hong \& Cho, 2011; Reichheld et al., 2000).

Customers perceive a higher level of risk with online retailers in terms of delivery, payment, and information disclosure. Hence, online customers prefer to transact with the online vendors they trust (Chiu, Huang, \& Yen, 2010; Pavlou \& Gefen, 2005; Singh \& Sirdeshmukh, 2000). The direction of relationship between satisfaction and trust is conceptualised both ways in the past literature. Some proposed satisfaction as a predictor of trust (e.g., Chung \& Shin, 2010; Kassim \& Abdullah, 2010), while most of the scholars consider trust as the predictor of customer satisfaction in online settings (Gummerus et al., 2004; Harris \& Goode, 
2004; Lin \& Wang, 2006; López-Miguens \& Vázquez, 2017; Jin \& Park, 2006). Finally, a recent meta-analysis on antecedents and consequences of trust in an online context report that online trust is the strongest predictor of customer online satisfaction with a website (Kim \& Peterson, 2017). Based on the above arguments and justifications, we propose that customer perception of trust is directly related to satisfaction in the online context.

H5: Trust has a positive impact on customers' satisfaction towards the online business.

\section{Relationship between Online Trust, Satisfaction, and Retail Brand Equity}

In the last three decades, offline brand equity has attracted a great deal of research interest. Aaker (1991) defined brand equity as a "set of brand assets and liabilities associated with a brand, its name and symbol that add to or subtract from the value provided by a product or service to a company and/or to that company's customer" (p. 15). Thus, brand equity offers both a financial as well as a psychological value for a brand (Christodoulides et al., 2006; Schultz, 2003).

There appears to be a consensus of opinion among scholars that brand equity is important for offline businesses (Page \& Lepkowska-White, 2002; Yoo et al., 2000). Interestingly, several researchers are of the view that it is even more important in the online business environment for firms to build their brand equity (Hilton, 2002; Mazur, 2001; Sealey, 1999). Online brand equity is different in the way it is created rather than its outcome. Unlike offline brand equity, online brand equity is co-created through the interaction between customer and a retailer; second, it is not forced upon consumer through associations; and thirdly, it is the outcome of both online and offline experience of customer with the brand (Christodoulides \& De Chernatony, 2010).

Although brand equity has been extensively investigated in offline contexts, the topic is generally ignored in the online context apart from a few exceptions. More importantly, both in the online and offline service contexts, the role of satisfaction in generating brand equity rarely receive proper research attention. Thus, it is not surprising to find very few studies have investigated the direct or indirect relationship between customer satisfaction and brand equity in a service context (Ha, Janda, \& Muthaly, 2010; Kao \& Lin, 2016; Kim, Zhao, \& Yang, 2008; Pappu $\&$ Quester, 2006). Those who did investigate the relationship between customer satisfaction and brand equity generally find a positive relationship. For example, in offline context, past research did find a positive relationship between student satisfaction and university brand equity (Dennis, Papagiannidis, Alamanos, \& 
Bourlakis, 2016), customer satisfaction with green brands on green brand equity (Chen, 2010), and customer satisfaction with a banking service and its impact on brand equity of a bank (Iglesias, Markovic, \& Rialp, 2018). In the online context both Kao and Lin (2016) and Kim et al. (2008) found a positive relationship between customer online satisfaction and e-brand equity. Based on the above discussion, there is a great need to further investigate and validate the positive relationship between customer satisfaction and brand equity in an online context. This study also proposes a positive relationship between customer satisfaction and brand equity in online environment:

H6: Customers' satisfaction has a positive impact on the brand equity of the online business.

The role of brand trust in building the brand equity has failed to receive much attention in the branding literature (Chaudhuri \& Holbrook, 2001). As the consumer-based brand equity is primarily a relational based asset, its maintenance depends on managing consumer trust with the organisation (Delgado-Ballester \& Munuera-Alemán, 2005; Morgan \& Hunt, 1994). This idea is further supported by the argument that the unique value of a brand perceived by consumers is largely due to the fact that the focal brand is in a superior position to offer trustworthiness as compared to other brands (Chaudhuri \& Holbrook, 2001; Delgado-Ballester \& Munuera-Alemán, 2005). As the risk factor is considered much higher in the online retailing context, we assume that existing consumer trust in an online brand will positively influence the e-brand equity of that retailer. Therefore, we propose the following hypothesis:

H7: Consumers' trust has a positive impact on the brand equity of the online business.

Based on the above hypotheses and relevant literature, we propose an integrated model of consumer-based e-retail equity (Figure 1). Apart from our proposed model, the past literature suggests multiple alternative models explaining the relationship between service quality and brand equity. For example, some researchers explore the direct relationship between overall service quality and overall brand equity (Çifci et al., 2016; Swoboda et al., 2016; Yoo \& Donthu, 2001). Others have used the parcelling method to convert SERVQUAL dimension as first order indicators of service quality construct and test its direct or indirect relationship with brand equity (Kassim \& Abdullah, 2010). Furthermore, many researchers have used a combination of mediating variables such as perceived value, trust, satisfaction, corporate credibility, and loyalty to explain the relationship between service quality dimensions and brand equity (Kao \& Lin 2016; Rios \& Riquelme, 2010). 


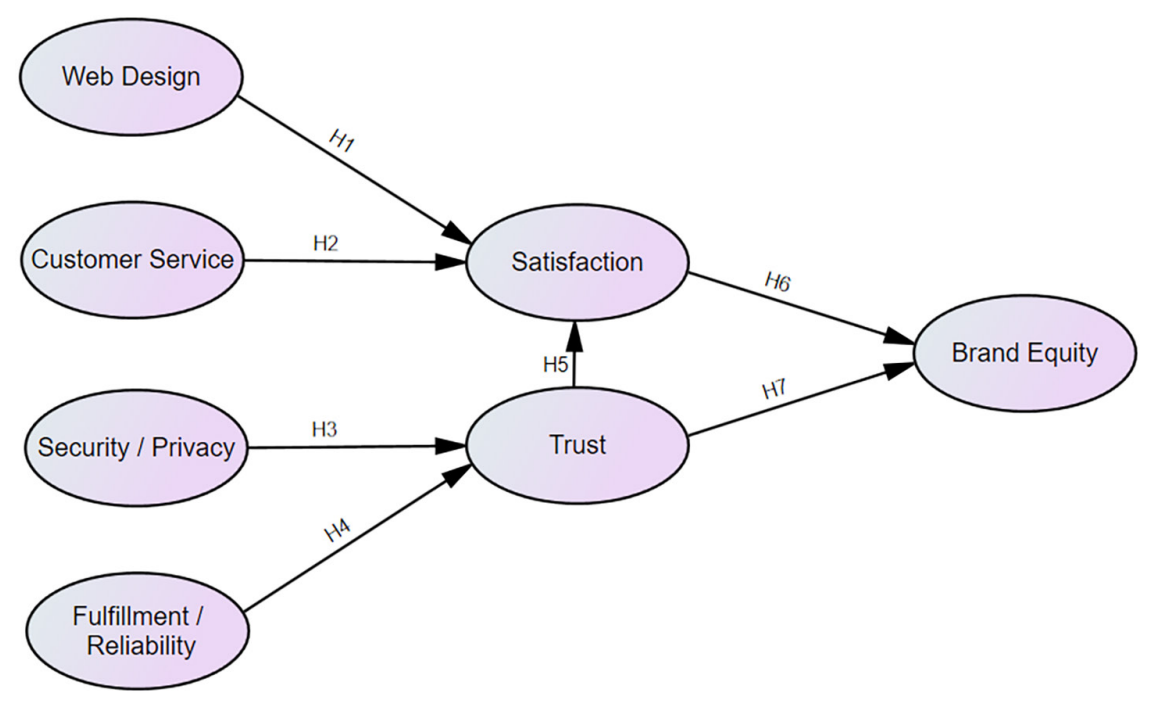

Figure 1. Conceptual model

We tested two alternative models (Figure 2), which in our view might help to further enhance our understanding. First, we did not find any research that explores the direct relationship between each dimension of e-retail service quality and brand equity. Thus, we tested a model that proposes a direct relationship between each e-retail service quality dimensions and overall e-retail brand equity (model 2). Second, using the parcelling technique, we created composite variables for each e-retail service quality dimension and used them as indicators to reflect the first order service quality construct. Using this first order e-retailing service quality construct, we tested its relationship with e-retail brand equity through trust and satisfaction (model 3).

\section{METHODOLOGY}

\section{Participants and Procedure}

A survey-based approach using a structured questionnaire was applied to collect data from the consumers who have the recent experience of purchasing online from Taobao, the largest e-retailing website of China (Gao, Chan, Chi, \& Deng, 2016). In the first section, consumers were asked to respond to questions related to their online shopping experience. The questions were used to find out whether they have used the Taobao shopping platform, the frequency of their visit to the Taobao website in last three months, and the average amount of money they spend 

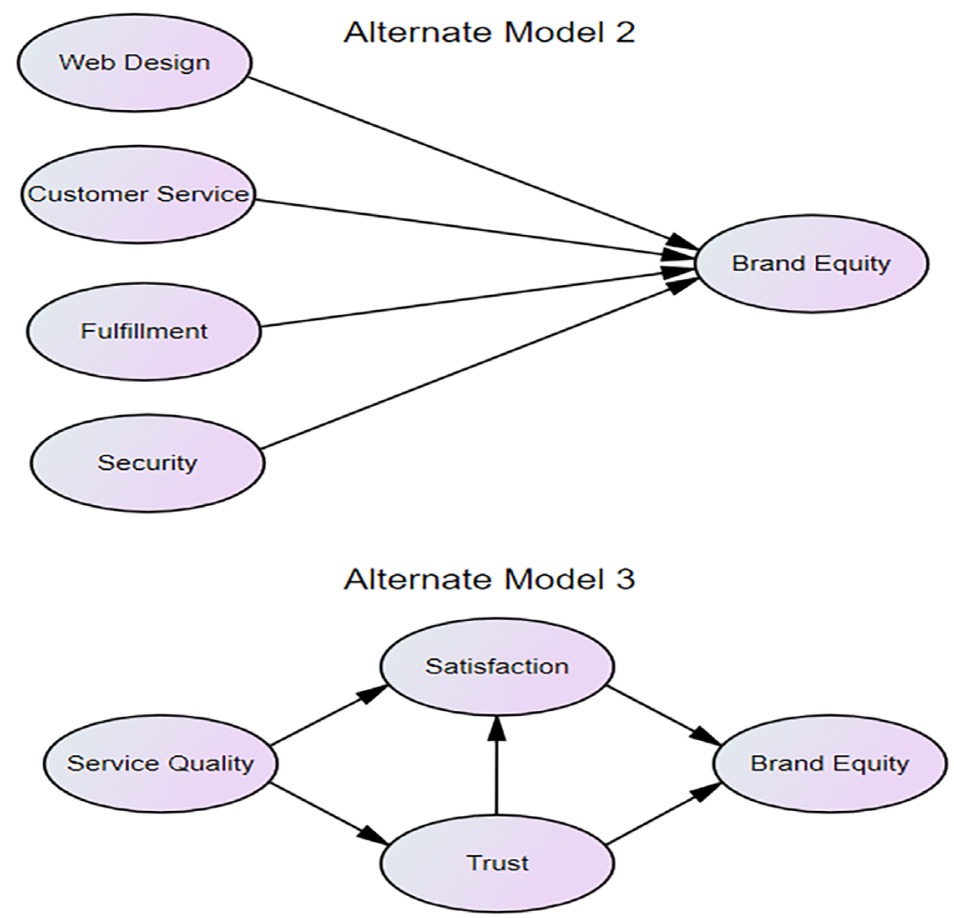

Figure 2. Alternative models

on each visit. In the second section, consumers were asked to record their opinions and perception towards Taobao's online retail quality, trust, satisfaction, and brand equity. The third section collected information about respondents' demographic and socio-economic characteristics such as gender, age, education, occupation, and income. A purposive sampling method was used in this research as it is practically appropriate in studying the e-retailing service quality dimensions, trust, satisfaction, and brand equity of China's e-retailing website, i.e. Taobao (Bernard, 2002; Tongco, 2007). The data collection process was conducted in the city of Shanghai where respondents, who have purchased from Taobao, were invited to participate in an online survey. Five hundred respondents were approached, from which 317 responses were obtained, yielding a $63 \%$ response rate.

\section{Measures}

Although several researchers have developed scales to measure e-service quality (Liu \& Arnett, 2000; Loiacono, Watson, \& Goodhue, 2002; Yoo \& Donthu, 2001), some have gained more acceptance than others (for a detailed review please refer to Blut et al., 2015). However, in the e-retailing context, the scale developed by 
Wolfinbarger and Gilly (2003) is considered as more robust, relevant, and context specific. Therefore, this study has adopted their four-dimensional, 14 items scale to measure e-retail quality. Online trust and satisfaction was measured using scales from Ribbink et al. (2004) study of consumer online behaviour. Yoo and Donthu's (2001) four items scale was used to measure overall brand equity.

\section{RESULTS AND DISCUSSION}

\section{Descriptive}

In the first step of data analysis, the data were examined for missing values. Past research suggests that a random omission of less than $5 \%$ per construct is acceptable and these missing values can be replaced using the mean substitution procedure (Tabachnick \& Fidell, 1983). In the first stage of dealing with the problem, all the missing values were initially coded with " 0 " in SPSS. This was followed by calculating the percentage of missing values in the data. A total of 42 missing values were identified in the data set and were replaced using the mean substitution procedure (Meyers, Gamst, \& Guarino, 2006). Subsequently, we used G*Power v3.1 to assess the minimum sample size for this study (Faul, Erdfelder, Lang, \& Buchner, 2007; Balaji, Khong, \& Chong, 2016). Given the main hypothesised model in Figure 1, with a medium effect size of $f^{2}=0.15$ and 24 predictors, the minimum sample size required is 238 . Consequently, the 317 responses from the survey was deemed adequate. SEM was then used to establish the proposed relationship between the constructs. Table 1 provides the demographic details of the respondents.

\section{Measurement Model Validation}

The SmartPLS2.0 software, a variance-based SEM approach, was used to simultaneously estimate the measurement and structural models (Hair, Hult, Ringle, \& Sarstedt, 2016). We began our analysis by evaluating the measurement model. Based on Hair et al. (2016) recommendations, internal consistency of the measurement model was assessed using composite reliability (CR), indicator reliability (IR), and average variance extracted (AVE). For discriminant validity, the Fornell-Larcker criterion was used (Fornell \& Larcker, 1981). As shown in Table 2, all the CR estimates and AVE values were above their respective cut-offs; however, this was not the case for indicator reliability. Following Hair et al. (2016) recommendations, we removed one item from the fulfilment and one from the web design constructs due to their poor indicator reliabilities. 
Table 1

Respondent profile

\begin{tabular}{|c|c|c|}
\hline Variable & Frequency & Percentage \\
\hline \multicolumn{3}{|l|}{ Gender } \\
\hline Male & 164 & 51.7 \\
\hline Female & 153 & 48.3 \\
\hline \multicolumn{3}{|l|}{ Age in years } \\
\hline$<20$ & 33 & 10.4 \\
\hline $20-30$ & 262 & 82.6 \\
\hline $31-40$ & 19 & 6.0 \\
\hline $41-50$ & 3 & 1.0 \\
\hline \multicolumn{3}{|l|}{ Education } \\
\hline Below secondary & 4 & 1.3 \\
\hline Secondary & 7 & 2.2 \\
\hline Polytechnic/diploma & 72 & 22.7 \\
\hline University/bachelor degree & 199 & 62.8 \\
\hline Master's degree & 33 & 10.4 \\
\hline Others & 2 & 0.6 \\
\hline \multicolumn{3}{|l|}{ Occupation } \\
\hline Professional & 93 & 29.3 \\
\hline Executive/manager & 4 & 1.3 \\
\hline Administrative & 34 & 10.7 \\
\hline Self-employed/own business & 21 & 6.6 \\
\hline Unemployed & 10 & 3.2 \\
\hline Housewife & 4 & 1.3 \\
\hline Retiree & 2 & 0.6 \\
\hline Student & 104 & 32.8 \\
\hline Others & 45 & 14.2 \\
\hline \multicolumn{3}{|l|}{ Monthly income in Yuan } \\
\hline$<153000$ & 65 & 20.5 \\
\hline $153000-200000$ & 54 & 17.0 \\
\hline 200001-300000 & 96 & 30.3 \\
\hline $300001-400000$ & 49 & 15.5 \\
\hline $400001-500000$ & 22 & 6.9 \\
\hline$>500000$ & 31 & 9.8 \\
\hline
\end{tabular}


Table 2

Construct validity

\begin{tabular}{|c|c|c|c|c|c|c|c|}
\hline Latent variable & Indicators & Loadings & IR & $\mathrm{CR}$ & AVE & $\mathrm{R}^{2}$ & Note \\
\hline Website design & & & & & & & WD2 \\
\hline $\begin{array}{l}\text { Taobao.com provides in-depth } \\
\text { information }\end{array}$ & WD1 & 0.70 & 0.49 & 0.82 & 0.53 & & removed \\
\hline $\begin{array}{l}\text { It is quick and easy to complete a } \\
\text { transaction at Taobao.com }\end{array}$ & WD3 & 0.71 & 0.50 & & & & \\
\hline $\begin{array}{l}\text { The level of personalisation at } \\
\text { Taobao.com is about right, not } \\
\text { too much or too little }\end{array}$ & WD4 & 0.71 & 0.51 & & & & \\
\hline Taobao.com has good selection & WD5 & 0.79 & 0.63 & & & & \\
\hline \multicolumn{8}{|l|}{ Customer service } \\
\hline $\begin{array}{l}\text { Taobao.com is willing and ready to } \\
\text { respond to customer needs }\end{array}$ & CSER1 & 0.86 & 0.75 & 0.89 & 0.73 & & \\
\hline $\begin{array}{l}\text { When you have a problem, Taobao. } \\
\text { com shows a sincere interest in } \\
\text { solving it }\end{array}$ & CSER2 & 0.88 & 0.78 & & & & \\
\hline $\begin{array}{l}\text { Inquiries are answered promptly at } \\
\text { Taobao.com }\end{array}$ & CSER3 & 0.81 & 0.65 & & & & \\
\hline \multicolumn{8}{|l|}{ Fulfilment/reliability } \\
\hline $\begin{array}{l}\text { Product that came was represented } \\
\text { accurately by Taobao.com }\end{array}$ & FUL1 & 0.87 & 0.77 & 0.83 & 0.71 & & $\begin{array}{c}\text { FUL3 } \\
\text { removed }\end{array}$ \\
\hline $\begin{array}{l}\text { You get what you ordered from } \\
\text { Taobao.com }\end{array}$ & FUL2 & 0.81 & 0.66 & & & & \\
\hline \multicolumn{8}{|l|}{ Security/privacy } \\
\hline $\begin{array}{l}\text { I feel like my privacy is protected at } \\
\text { Taobao.com }\end{array}$ & SEC1 & 0.77 & 0.60 & 0.88 & 0.71 & & \\
\hline $\begin{array}{l}\text { I feel safe in my transactions with } \\
\text { Taobao.com }\end{array}$ & SEC2 & 0.87 & 0.76 & & & & \\
\hline $\begin{array}{l}\text { Taobao.com has adequate security } \\
\text { features }\end{array}$ & SEC3 & 0.88 & 0.78 & & & & \\
\hline \multicolumn{8}{|l|}{ Trust } \\
\hline $\begin{array}{l}\text { I am prepared to give private } \\
\text { information to Taobao.com }\end{array}$ & TRU1 & 0.80 & 0.64 & 0.86 & 0.60 & 0.31 & \\
\hline $\begin{array}{l}\text { I am willing to give my credit card } \\
\text { number to Taobao.com }\end{array}$ & TRU2 & 0.79 & 0.62 & & & & \\
\hline $\begin{array}{l}\text { It is not a problem to pay in advance } \\
\text { for purchased products over } \\
\text { Taobao.com }\end{array}$ & TRU3 & 0.74 & 0.54 & & & & \\
\hline $\begin{array}{l}\text { Taobao.com intends to fulfil their } \\
\text { promises }\end{array}$ & TRU4 & 0.78 & 0.61 & & & & \\
\hline
\end{tabular}


Table 2 (continued)

\begin{tabular}{|c|c|c|c|c|c|c|c|}
\hline Latent variable & Indicators & Loadings & IR & $\mathrm{CR}$ & AVE & $\mathrm{R}^{2}$ & Note \\
\hline \multicolumn{8}{|l|}{ Customer satisfaction } \\
\hline $\begin{array}{l}\text { I am generally pleased with Taobao. } \\
\text { com's online services }\end{array}$ & SAT1 & 0.75 & 0.57 & 0.89 & 0.67 & 0.44 & \\
\hline Taobao.com is enjoyable & SAT2 & 0.81 & 0.66 & & & & \\
\hline $\begin{array}{l}\text { I am very satisfied with Taobao. } \\
\text { com's online services }\end{array}$ & SAT3 & 0.83 & 0.70 & & & & \\
\hline I am happy with Taobao.com & SAT4 & 0.86 & 0.75 & & & & \\
\hline \multicolumn{8}{|l|}{ Brand equity } \\
\hline $\begin{array}{l}\text { It makes sense to buy on Taobao. } \\
\text { com instead of any other site } \\
\text { even if they are same }\end{array}$ & BE1 & 0.84 & 0.71 & 0.91 & 0.73 & 0.31 & \\
\hline $\begin{array}{l}\text { Even if another site has the same } \\
\text { features as Taobao.com, I would } \\
\text { prefer to buy on this site }\end{array}$ & BE2 & 0.89 & 0.80 & & & & \\
\hline $\begin{array}{l}\text { If there is another site as good as } \\
\text { Taobao.com, I prefer to buy } \\
\text { from Taobao.com }\end{array}$ & BE3 & 0.86 & 0.74 & & & & \\
\hline $\begin{array}{l}\text { If another site is not different from } \\
\text { Taobao.com in any way, it } \\
\text { seems smarter to purchase from } \\
\text { Taobao.com }\end{array}$ & BE4 & 0.83 & 0.68 & & & & \\
\hline
\end{tabular}

Note: $\mathrm{WD}=$ web design, $\mathrm{SAT}=$ customer satisfaction, $\mathrm{CSER}=$ customer service, $\mathrm{SEC}=$ security, TRU $=$ trust, $\mathrm{BE}=$ brand equity, $\mathrm{FUL}=$ fulfilment

Discriminant validity was assessed using Fornell-Larcker criterion (Table 3). The bold numbers on the diagonal are the square root of each construct's AVE while the off-diagonal values in the matrix are the correlations between the latent constructs. Evidently, the results indicate that discriminant validity was not an issue in this study, since the square root of AVE values were substantially higher than any correlation with a respective construct (Fornell \& Larcker, 1981).

Table 3

Discriminant validity

\begin{tabular}{lccccccc}
\hline & WD & CSER & FUL & SEC & TRU & SAT & BE \\
\hline Web design & $\mathbf{0 . 7 3}$ & & & & & & \\
Customer service & 0.34 & $\mathbf{0 . 8 5}$ & & & & & \\
Fulfilment/reliability & 0.59 & 0.34 & $\mathbf{0 . 8 4}$ & & & & \\
Security/privacy & 0.49 & 0.43 & 0.43 & $\mathbf{0 . 8 4}$ & & & \\
Trust & 0.39 & 0.39 & 0.41 & 0.51 & $\mathbf{0 . 7 7}$ & & \\
Satisfaction & 0.52 & 0.52 & 0.48 & 0.45 & 0.46 & $\mathbf{0 . 8 2}$ & \\
Brand equity & 0.37 & 0.35 & 0.29 & 0.20 & 0.34 & 0.55 & $\mathbf{0 . 8 5}$ \\
\hline
\end{tabular}




\section{Structural Model and Hypotheses Testing}

Having performed the reliability and validity assessments of the constructs, we moved to the next step of evaluating the structural model. This involves examining the predictive capabilities of the proposed model and the relationships between the constructs (Hair et al., 2016). We followed Hair et al. (2016) five-step approach for assessing the structural model in PLS-SEM. Firstly, the model was tested for multi collinearity. The variance inflation factor (VIF) values for each of the constructs were lower than the cut of value of 3.3 (Diamantopoulos \& Siguaw, 2006). Hence, there is no issue of collinearity in this study.

Secondly, we performed PLS-SEM algorithms to obtain the path estimates in the structural model. Then, a bootstrapping re-sampling procedure $(5,000$ samples $)$ was executed to obtain the standard error, which in turns allows the computation of statistical significance of these path coefficients. Table 4 presents the results of the hypotheses testing. Our results indicate that all coefficients were statistically significant and in line with the proposed direction (H1 to H7).

Thirdly, using the rule of thumb, $\mathrm{R}^{2}$ values of $0.75,0.50$, and 0.25 can be described as substantial, moderate, and weak, respectively (Hair et al., 2016). In addition to $\mathrm{R}^{2}$, Hair et al. (2016) suggested additional two steps for evaluating a structural model in PLS-SEM. The first is assessing the effect size $\left(f^{2}\right)$ and second is measuring the predictive relevance $\left(\mathrm{Q}^{2}\right)$. In accordance with their guidelines for assessing $f^{2}$, values of $0.02,0.15$, and 0.35 represent small, medium, and large effects of the exogenous latent variables, respectively (Hair et al., 2016). Finally, we also examined the $\mathrm{Q}^{2}$ value, which is an indicator of the model's predictive relevance (Hair et al., 2016). $Q^{2}$ values larger than zero for a reflective endogenous latent variable indicate the path model's predictive relevance for a particular construct (Hair et al., 2014).

Table 4

Results of hypothesis testing

\begin{tabular}{llccccc}
\hline & Path & $\begin{array}{c}\text { Path } \\
\text { coefficients, } \beta\end{array}$ & $\begin{array}{c}\text { Sample mean } \\
(\mathrm{M})\end{array}$ & Std. error & $t$-statistics & Decision \\
\hline H1 & WD to SAT & 0.33 & 0.34 & 0.05 & $5.82^{* *}$ & Supported \\
H2 & CSER to SAT & 0.33 & 0.32 & 0.05 & $5.99^{* *}$ & Supported \\
H3 & SEC/PRV to TUS & 0.40 & 0.40 & 0.05 & $7.37^{* *}$ & Supported \\
H4 & FUL/REL to TUS & 0.23 & 0.24 & 0.05 & $4.26^{* *}$ & Supported \\
H5 & TRU to SAT & 0.19 & 0.19 & 0.05 & $3.59^{* *}$ & Supported \\
H6 & SAT to BE & 0.49 & 0.49 & 0.05 & $9.25^{* *}$ & Supported \\
H7 & TRU to BE & 0.11 & 0.11 & 0.05 & $1.97^{*}$ & Supported \\
\hline
\end{tabular}

Note: $t$-values for two-tailed tests ${ }^{*} p<0.05$ ( $t$-value 1.96$),{ }^{* *} p<0.01$ ( $t$-value 2.57 ) 
Table 5 presents the assessment of co-efficient of determination $\left(\mathrm{R}^{2}\right)$, effect size $\left(f^{2}\right)$, and predictive relevance $\left(\mathrm{Q}^{2}\right)$ of exogenous variables on endogenous variable in this study. The value for $\mathrm{R}^{2}$ is 0.312 for brand equity, 0.441 for customer satisfaction, and 0.310 for trust. The findings of $\mathrm{Q}^{2}$ again show that there is predictive relevance for the endogenous variables (Hair et al., 2016). The findings of $f^{2}$ for exogenous variables are vary. Although the effect of trust on brand equity is significant, the exogenous variable does not carry much effect. We run blindfolding procedure to obtain the cross-validated redundancy as a measure of $\mathrm{Q}^{2}$ for reflective endogenous constructs. As a result, all $\mathrm{Q}^{2}$ values were significantly above zero, indicating that the model has predictive relevance.

Table 5

Determination of $R^{2}, f^{2}$, and $Q^{2}$ for model 1

\begin{tabular}{lllll}
\hline Construct & $\mathrm{R}^{2}$ & $\mathrm{Q}^{2}$ & & \multicolumn{1}{c}{$f^{2}$} \\
& & & WD to SAT & 0.16 (medium) \\
& & & CSR to SAT & 0.15 (medium) \\
SAT & 0.44 & 0.28 & FUL to TRU & 0.06 (small) \\
TRU & 0.31 & 0.18 & SEC to TRU & 0.19 (medium) \\
BE & 0.31 & 0.22 & TRU to SAT & 0.05 (none) \\
& & & SAT to BE & 0.28 (medium) \\
& & & TRU to BE & 0.01 (none) \\
\hline
\end{tabular}

\section{Customer Online Satisfaction as a Mediator between Trust and E-Retail Brand Equity}

Mediation analysis was performed following the guidelines of Hair et al. (2016) and Preacher and Hayes (2004). Using the bootstrapping procedure, we first assessed the significance of the direct effect without including the mediator variable in the PLS path model. If the direct effect is not significant, there is no mediating effect. Our results showed that there was significant direct effect of trust on brand equity without satisfaction as mediator, thus we proceed by including satisfaction as mediator to assess the significance of the indirect effect. The results suggest a significant indirect effect. We moved to the final step by assessing the variance accounted for (VAF) value. VAF values that are less than $20 \%$ indicates no mediation, VAF larger than $20 \%$ and less than $80 \%$ is categorised as partial mediation, and VAF value above $80 \%$ represent full mediation (Hair et al., 2016). The result showed a VAF value of 0.46 which means customer satisfaction partially mediates trust and brand equity as shown in Table 6 . 
Table 6

Mediating effects

\begin{tabular}{lccccc}
\hline & $\begin{array}{c}\text { Direct } \\
\text { effect }\end{array}$ & $\begin{array}{c}\text { Indirect } \\
\text { effect }\end{array}$ & $\begin{array}{c}\text { Total } \\
\text { effect }\end{array}$ & VAF & Results \\
\hline Trust to satisfaction to brand equity & $0.11^{*}$ & $0.09^{* *}$ & $0.21^{*}$ & 0.46 & Partial mediation \\
\hline
\end{tabular}

Note: ${ }^{* *}$ significant at $p<0.01$; ${ }^{*}$ significant at $p<0.05$

\section{Alternative Models Testing and Measurement Model Validation}

Table 7 provides the assessment of construct reliability as well as convergent validity for the variables of two alternative models. All the constructs have construct reliability score above 0.70 thus establishing internal consistency. Similarly, these constructs demonstrate good convergent validity as they achieve minimum threshold value of 0.5 for AVE (Hair et al., 2016).

Table 7

Internal consistency and convergent validity

\begin{tabular}{|c|c|c|c|c|c|}
\hline Model & Construct & Item & Loading & $\mathrm{CR}$ & AVE \\
\hline \multirow[t]{17}{*}{ Model 2} & WD & WD 1 & 0.74 & 0.82 & 0.53 \\
\hline & & WD 3 & 0.68 & & \\
\hline & & WD 4 & 0.72 & & \\
\hline & & WD 5 & 0.77 & & \\
\hline & CSER & CSR1 & 0.87 & 0.88 & 0.72 \\
\hline & & CSR2 & 0.89 & & \\
\hline & & CSR3 & 0.78 & & \\
\hline & SEC & SEC1 & 0.83 & 0.88 & 0.71 \\
\hline & & SEC2 & 0.86 & & \\
\hline & & SEC3 & 0.83 & & \\
\hline & FUL & FUL1 & 0.77 & 0.79 & 0.57 \\
\hline & & FUL2 & 0.77 & & \\
\hline & & FUL3 & 0.72 & & \\
\hline & $\mathrm{BE}$ & BE1 & 0.85 & 0.91 & 0.73 \\
\hline & & BE2 & 0.90 & & \\
\hline & & BE3 & 0.85 & & \\
\hline & & BE4 & 0.81 & & \\
\hline
\end{tabular}

(continued on next page) 
Table 7 (continued)

\begin{tabular}{lllccc}
\hline Model & Construct & Item & Loading & CR & AVE \\
\hline Model 3 & SQ & WD & 0.77 & 0.85 & 0.60 \\
& & CSR & 0.79 & & \\
& & FUL & 0.82 & & \\
& & SEC & 0.70 & & \\
& SAT & SAT1 & 0.75 & 0.89 & 0.67 \\
& & SAT2 & 0.81 & & \\
& & SAT3 & 0.84 & & \\
& & SAT4 & 0.86 & & \\
& TRU & TRU1 & 0.79 & 0.86 & 0.60 \\
& & TRU2 & 0.79 & & \\
& & TRU3 & 0.73 & & \\
& & TRU4 & 0.78 & & \\
& & BE1 & 0.84 & 0.91 & 0.73 \\
& & BE2 & 0.89 & & \\
& & BE3 & 0.86 & & \\
& & BE4 & 0.83 & & \\
\hline
\end{tabular}

Table 8 presents the results of discriminant validity test using the Fornell-Larcker (1981) criterion for models 2 and 3. As illustrated, the square root of AVE of each construct is larger than the correlation estimates of the constructs. This establishes the discriminant validity of our measurement model.

Table 8

Discriminant validity

\begin{tabular}{lllllll}
\hline Model 2 & & WD & CSER & FUL & SEC & BE \\
\cline { 2 - 7 } & WD & 0.73 & & & & \\
& CSER & 0.34 & 0.85 & & & \\
& FUL & 0.63 & 0.42 & 0.75 & & \\
& SEC & 0.49 & 0.44 & 0.51 & 0.84 & \\
& BE & 0.38 & 0.35 & 0.33 & 0.21 & 0.85 \\
\hline Model 3 & & SQ & SAT & TRU & BE & \\
& SQ & 0.77 & & & & \\
& SAT & 0.64 & 0.82 & & & \\
& TRU & 0.54 & 0.46 & 0.77 & & \\
& BE & 0.39 & 0.55 & 0.34 & 0.85 & \\
\hline
\end{tabular}


Finally, it is important to ensure that there is no collinearity in the structural model. The VIF values for all exogenous constructs is lower than the offending value of 3.3 (Diamantopoulos \& Siguaw, 2006), thus, suggesting that there is no issue of collinearity in this study.

\section{Structural Model Estimations}

We proposed in model 2 that web design, customer service, fulfilment/reliability, and security were direct predictors of consumer-based e-brand equity. The results of structural model suggest that only customer service and web design are direct predictors of consumer-based e-brand equity (see Table 9). Results of structural model proposed in model 3 suggest that all the relationships were significant (Table 9).

Table 9

Path co-efficient assessment

\begin{tabular}{llcccc}
\hline Model & Relationship & Direct effect $(\beta)$ & Standard error & $t$-statistic & $p$-value \\
\hline Model 2 & WD $\rightarrow$ BE & 0.27 & 0.07 & $3.86^{* *}$ & 0.00 \\
& CSER $\rightarrow$ BE & 0.25 & 0.05 & $4.57^{* *}$ & 0.00 \\
& FUL $\rightarrow$ BE & 0.10 & 0.07 & 1.40 & 0.16 \\
& SEC $\rightarrow$ BE & -0.08 & 0.05 & 1.50 & 0.13 \\
Model 3 & SQ $\rightarrow$ SAT & 0.55 & 0.05 & $9.78^{* *}$ & 0.00 \\
& SQ $\rightarrow$ TRU & 0.54 & 0.04 & $12.92^{* *}$ & 0.00 \\
& TRU $\rightarrow$ SAT & 0.16 & 0.06 & $2.59^{* *}$ & 0.01 \\
& SAT $\rightarrow$ BE & 0.49 & 0.05 & $8.86^{* *}$ & 0.00 \\
& TRU $\rightarrow$ BE & 0.11 & 0.06 & $1.85^{*}$ & 0.03 \\
\hline
\end{tabular}

Note: $t$-values for two-tailed tests ${ }^{*} p<0.05$ (t-value 1.96$),{ }^{* *} p<0.01$ ( $t$-value 2.57$)$

Table 10 presents the assessment of $\mathrm{R}^{2}, f^{2}$ as well as $\mathrm{Q}^{2}$ of exogenous variable on endogenous variable for the two alternative models. In model 2 , the value for $\mathrm{R}^{2}$ is 0.211 . Comparatively, the variance explained in this model $(21.1 \%)$ is lowest as compared to original model (model 1,31.0\%). $\mathrm{Q}^{2}$ value for brand equity is also larger than zero (Hair et al., 2016), assuring predictive relevance of endogenous variables. The effect sizes of customer service and fulfilment on brand equity are found to be small. In model 3 , the value for $\mathrm{R}^{2}$ is $0.313,0.429$, and 0.293 for brand equity, customer satisfaction, and trust, respectively, meaning that they explain $31.3 \%, 42.9 \%$, and $29.3 \%$ of variances in their respective models. Overall, all $\mathrm{Q}^{2}$ values are larger than zero (Hair et al., 2016), hence, indicating predictive quality of the endogenous variables. Service quality is found to have large effect size on customer satisfaction and trust $\left(\mathrm{SQ}, f^{2}=0.378 ; f^{2}=0.414\right)$. Model 3 has a slightly higher $\mathrm{R}^{2}$ as compared to original model. 
Table 10

Determination of $R^{2}, f^{2}$, and $Q^{2}$ for models 2 and 3

\begin{tabular}{lllll}
\hline Constructs & $\mathrm{R}^{2}$ & $\mathrm{Q}^{2}$ & & $f^{2}$ \\
\hline & & & WD to BE & 0.053 (small) \\
& & & CSR to BE & 0.063 (small) \\
& & & FUL to BE & 0.007 (none) \\
BE & 0.21 & 0.140 & SEC to BE & 0.006 (none) \\
& & & SQ to SAT & 0.370 (large) \\
& & & SQ to TRU & 0.410 (large) \\
SAT & 0.42 & 0.280 & TRU to SAT & 0.030 (small) \\
BE & 0.31 & 0.226 & SAT to BE & 0.240 (large) \\
TRU & 0.29 & 0.170 & TRU to BE & 0.010 (small) \\
\hline
\end{tabular}

\section{CONCLUSION, IMPLICATIONS, AND LIMITATIONS}

Research on e-retailing is now focused on understanding the impact of firms' branding initiatives on consumer perceptions and preferences. Therefore, this study contributes to the existing literature by identifying the important antecedents of e-retail brand equity and their interrelationships. One of the important contributions of this study is to provide some evidence that how different conceptualisations of the relationship between e-retail quality and online brand equity can lead managers towards slightly different conclusions. Model 1 perhaps has the strongest theoretical foundations. If a manager is using this model as a lens to understand relationships among several constructs in our model, he/she will conclude that satisfaction is the strongest direct antecedents that also plays a mediating role between online trust and online brand equity of a retailer. The second thing a manager will notice is the strong relationship between privacy and trust on an online retailer. Thus, he will assume that ensuring customer data privacy and security will help in generating customer trust, which has positive relationship with both satisfaction and retailer online brand equity.

These results are also in line with the past studies suggesting that security/privacy concerns are significant in the online context and strongly influence trustworthiness of a website (Aiken \& Bousch, 2006; Hoffman et al., 1999; Kim et al., 2009; Ribbink et al., 2004). Thus, it is logical to assume that online retail brands with sophisticated privacy and security procedures in place are more likely to build longterm customer relationships. In addition, our results also support earlier studies which showed that trust is one of the strongest predictor of customer satisfaction in the online context (Harris \& Goode, 2004; Lin \& Wang, 2006; Jin \& Park, 2006). 
The results of model 1 also showed that website design and customer service have a positive impact on customers' online satisfaction with the e-retail brand. These two antecedents of online satisfaction approximately explain $45 \%$ of the variance. Thus, in the online retailing context, creating a web design that provide seamless shopping experience supplemented by effective customer service mechanisms can significantly contribute to customer satisfaction in a meaningful way. These results are in line with past studies exploring the relationship between website design and customer service on consumers' online satisfaction (Devaraj et al., 2002; Kim et al., 2009; Shankar et al., 2002; Szymanski \& Hise, 2000; Zeithaml et al., 2002).

Thirdly, in model 1, trust and satisfaction were proposed as the direct antecedents of e-retail brand equity. In line with some recent studies, we found a positive relationship between satisfaction and e-brand equity, as well as between trust and e-brand equity (Kao \& Lin, 2016). Although one can notice that satisfaction appears to be a much stronger predictor of e-retail brand equity as compared to trust. However, this might be due to the fact that satisfaction is mediating the relationship between trust and retailer online brand equity.

The testing of alternative models suggests that the direct model (model 2) explain least amount of variance as compared to other two models. Nonetheless, the direct model provides some interesting insights. For example, it suggests that security and fulfilment are not the direct significant predictors of e-retail brand equity. On the other hand, website design and customer service dimensions have a direct significant influence on e-retail brand equity. These results indicate that how testing models based on weak conceptualisation can generate confusing results and the least predictive relevance. A manager using model 2 may assume that privacy/ security and fulfilment have no role in predicting an online retailer brand equity. This conclusion will not only be superficial but could become extremely costly for an online retailer. Model 3 presents marginally better results as compared to model 1 . In our view, model 3 provide quite similar results. One can notice that by using service quality as a uni-dimension construct, we are able to see how overall service quality strongly influence customer satisfaction and trust with an online retail brand. The second thing one can notice is that the beta value for the path between satisfaction and brand equity remain the same.

Online retailers can use our proposed model of e-brand equity not only to measure the perceptions of their own customers but also the customers of their competitors. This will allow the brand to establish a benchmark for improving its own e-retail quality and to identify its point of parity and point of difference in order to build sustainable competitive advantage. Unlike previous studies, this research 
expands our understanding by investigating the role of specific dimensions of e-retail quality on e-brand equity through trust and satisfaction. Thus, managers can use our conceptual model to capture perceptions of their existing customers towards their e-retail brand. For example, by using our main conceptual model (model 1), managers can collect data from their own customers to understand which relationships are weak in the model and therefore needs further attention. For example, if an e-retail brand finds out that the linkage between consumer perceptions of their website design and satisfaction is weak/poor, this should raise concerns. E-retailing firms could conduct a focus group study to validate quantitative results and further enhance their understanding about the reasons for their customers' poor perceptions towards their website design.

Online trust appears to be the strongest predictor of e-retail brand equity. Therefore, managers should consider investing in the processes that can further build their consumer brand trust. The privacy and security dimension of e-retail quality was the second strongest predictor of consumer trust on e-shopping in our model. This highlights the fact that online consumers are extremely concerned about the privacy and security of their personal information. The recent lapse in protecting consumer data by large corporations suggests that the consumer concern is genuine. Thus, building online brand preference based on fool-proof security of consumer personal information and transactional data can provide a stronger and long-term competitive advantage.

This research investigated the $\mathrm{B} 2 \mathrm{C}$ aspect of online retail branding; however, many online retailing platforms also provide $\mathrm{C} 2 \mathrm{C}$ opportunities. Thus, future research can test this model for brands which provide $\mathrm{C} 2 \mathrm{C}$ as well as the brands which offer both $\mathrm{B} 2 \mathrm{C}$ and $\mathrm{C} 2 \mathrm{C}$ transactions on their platforms. Online consumers often prefer these sites due to heavy discounts and other promotional campaigns. Therefore, future research can incorporate the impact of large scale promotional activities on consumer-based e-retail brand equity. It is also highly likely that online reviews, either from customer-generated ratings or experts, may have an influence on online purchase behaviour and we recommend that future studies should examine this new development. It is also highly likely that the mechanisms through which consumers formulate brand equity would vary across different demographics and future studies should take this into account. Finally, this research was conducted in China, and thus explores the issue based on the perceptions of these consumers; therefore, it is important to explore the issues in other countries to further validate the model. 


\section{REFERENCES}

Aaker, D.A. (1991). Managing brand equity. New York: Maxweel Macmillan-Canada.

Aiken, K.D., \& Boush, D.M. (2006). Trustmarks, objective-source ratings, and implied investments in advertising: Investigating online trust and the context-specific nature of internet signals. Journal of the Academy of Marketing Science, 34(3), 308-323. https://doi.org/10.1177/0092070304271004

Agag, G., El-Masry, A., Alharbi, N.S., \& Ahmed Almamy, A. (2016). Development and validation of an instrument to measure online retailing ethics: Consumers' perspective. Internet Research, 26(5), 1158-1180. https://doi.org/10.1108/IntR09-2015-0272

Alam, S.S., \& Yasin, N.M. (2010). An investigation into the antecedents of customer satisfaction of online shopping. Journal of Marketing Development and Competitiveness, 5(1), 71-78.

Atsmon, Y., Dixit, V., Magni, M., Narasimhan, L., \& Wu, C. (2010). Digital nation on the rise: Profiting from China's Internet revolution. McKinsey Quarterly Review, July.

Atsmon,Y., Dixit, V., Magni, M., \& St-Maurice, I. (2010). China's new pragmatic consumers. Retrieved 12 May 2017 from https://www.mckinsey.com/ business-functions/marketing-and-sales/our-insights/chinas-new-pragmaticconsumers?cid=soc-web

Anderson, R.E., \& Srinivasan, S.S. (2003). E-satisfaction and e-loyalty: A contingency framework. Psychology \& Marketing, 20(2), 123-138. https://doi.org/10.1002/ mar. 10063

Anselmsson, J., Burt, S., \& Tunca, B. (2017). An integrated retailer image and brand equity framework: Re-examining, extending, and restructuring retailer brand equity. Journal of Retailing and Consumer Services, 38, 194-203. https://doi.org/ 10.1016/j.jretconser.2017.06.007

Balaji, M.S., Khong, K.W., \& Chong, A.Y.L. (2016). Determinants of negative word-ofmouth communication using social networking sites. Information \& Management, 53(4), 528-540. https://doi.org/10.1016/j.im.2015.12.002

Barnes, S.J., \& Vidgen, R.T. (2002). An integrative approach to the assessment of e-commerce quality. Journal of Electronic Commerce Research, 3(3), 114-127.

Beldad, A., de Jong, M., \& Steehouder, M. (2010). How shall I trust the faceless and the intangible? A literature review on the antecedents of online trust. Computers in Human Behavior, 26(5), 857-869. https://doi.org/10.1016/j.chb.2010.03.013

Bernard, H.R. (2002). Research methods in anthropology: Qualitative and quantitative methods. Walnut Creek, CA: Altamira Press.

Bilgihan, A. (2016). Gen Y customer loyalty in online shopping: An integrated model of trust, user experience and branding. Computers in Human Behavior, 61, 103-113. https://doi.org/10.1016/j.chb.2016.03.014

Blut, M., Chowdhry, N., Mittal, V., \& Brock, C. (2015). E-service quality: A metaanalytic review. Journal of Retailing, 91(4), 679-700. https://doi.org/10.1016/j. jretai.2015.05.004 
Cai, S., \& Xu, Y. (2006). Effects of outcome, process and shopping enjoyment on online consumer behaviour. Electronic Commerce Research and Applications, 5(4), 272-281. https://doi.org/10.1016/j.elerap.2006.04.004

Cao, Y., Ajjan, H., \& Hong, P. (2018). Post-purchase shipping and customer service experiences in online shopping and their impact on customer satisfaction: An empirical study with comparison. Asia Pacific Journal of Marketing and Logistics, 30(2), 400-416. https://doi.org/10.1108/APJML-04-2017-0071

Chen, Y.S. (2010). The drivers of green brand equity: Green brand image, green satisfaction, and green trust. Journal of Business Ethics, 93(2), 307-319. https://doi.org/10.1007/s10551-009-0223-9

Chang, H.H., \& Wang, H.W. (2011). The moderating effect of customer perceived value on online shopping behaviour. Online Information Review, 35(3), 333-359. https://doi.org/10.1108/14684521111151414

Chaudhuri, A., \& Holbrook, M.B. (2001). The chain of effects from brand trust and brand affect to brand performance: The role of brand loyalty. Journal of Marketing, 65(2), 81-93. https://doi.org/10.1509/jmkg.65.2.81.18255

Chiu, C.M., Huang, H.Y., \& Yen, C.H. (2010). Antecedents of trust in online auctions. Electronic Commerce Research and Applications, 9(2), 148-159. https://doi.org/ 10.1016/j.elerap.2009.04.003

Chung, K.H., \& Shin, J.I. (2010). The antecedents and consequents of relationship quality in internet shopping. Asia Pacific Journal of Marketing and Logistics, 22(4), 473491. https://doi.org/10.1108/13555851011090510

Çifci, S., Ekinci, Y., Whyatt, G., Japutra, A., Molinillo, S., \& Siala, H. (2016). A cross validation of consumer-based brand equity models: Driving customer equity in retail brands. Journal of Business Research, 69(9), 3740-3747. https://doi. org/10.1016/j.jbusres.2015.12.066

Cristobal, E., Flavián, C., \& Guinaliu, M. (2007). Perceived e-service quality (PeSQ): Measurement validation and effects on consumer satisfaction and web site loyalty. Managing Service Quality: An International Journal, 17(3), 317-340. https://doi.org/10.1108/09604520710744326

Christodoulides, G., \& De Chernatony, L. (2010). Consumer-based brand equity conceptualization and measurement: A literature review. International Journal of Research in Marketing, 52(1), 43-66. https://doi.org/10.2501/ S1470785310201053

Christodoulides, G., De Chernatony, L., Furrer, O., Shiu, E., \& Abimbola, T. (2006). Conceptualising and measuring the equity of online brands. Journal of Marketing Management, 22(7-8), 799-825. https://doi.org/10.1362/026725706778612149

Corritore, C.L., Kracher, B., \& Wiedenbeck, S. (2003). On-line trust: Concepts, evolving themes, a model. International Journal of Human-Computer Studies, 58(6), 737758. https://doi.org/10.1016/S1071-5819(03)00041-7

Cyr, D. (2008). Modeling web site design across cultures: Relationships to trust, satisfaction, and e-loyalty. Journal of Management Information Systems, 24(4), 47-72. https://doi.org/10.2753/MIS0742-1222240402 
Delgado-Ballester, E., \& Munuera-Alemán, L.J. (2005). Does brand trust matter to brand equity? Journal of Product \& Brand Management, 14(3), 187-196. https://doi. org/10.1108/10610420510601058

Dennis, C., Papagiannidis, S., Alamanos, E., \& Bourlakis, M. (2016). The role of brand attachment strength in higher education. Journal of Business Research, 69(8), 3049-3057. https://doi.org/10.1016/j.jbusres.2016.01.020

Devaraj, S., Fan, M., \& Kohli, R. (2002). Antecedents of B2C channel satisfaction and preference: Validating e-commerce metrics. Information Systems Research, 13(3), 316-333. https://doi.org/10.1287/isre.13.3.316.77

Diamantopoulos, A., \& Siguaw, J.A. (2006). Formative versus reflective indicators in organizational measure development: A comparison and empirical illustration. British Journal of Management, 17(4), 263-282. https://doi.org/10.1111/j.14678551.2006.00500.x

Esch, F.R., Langner, T., Schmitt, B.H., \& Geus, P. (2006). Are brands forever? How brand knowledge and relationships affect current and future purchases. Journal of Product \& Brand Management, 15(2), 98-105. https://doi.org/10. 1108/10610420610658938

Fang, Y.H., Chiu, C.M., \& Wang, E.T. (2011). Understanding customers' satisfaction and repurchase intentions: An integration of IS success model, trust, and justice. Internet Research, 21(4), 479-503. https://doi.org/10.1108/10662241111158335

Faul, F., Erdfelder, E., Lang, A.G., \& Buchner, A. (2007). G* Power 3: A flexible statistical power analysis program for the social, behavioral, and biomedical sciences. Behavior Research Methods, 39(2), 175-191. https://doi.org/10.3758/ BF03193146

FinancialBuzz.com. (2018). Chinese e-retail sales pass USD1 billion mark as online shopping grows. Retrieved 20 November 2018 from https://www.prnewswire. com/news-releases/chinese-e-retail-sales-pass-usd-1-billion-mark-as-onlineshopping-grows-848117269.html

Fornell, C., \& Larcker, D.F. (1981). Evaluating structural equation models with unobservable variables and measurement error. Journal of Marketing Research, 18(1), 39-50. https://doi.org/10.2307/3151312

Gao, B., Chan, W.K.V., Chi, L., \& Deng, X.N. (2016). Size and growth dynamics of online stores: A case of China's Taobao.com. Electronic Commerce Research and Applications, 17, 161-172. https://doi.org/10.1016/j.elerap.2016.04.005

Grabner-Kraeuter, S. (2002). The role of consumers' trust in online-shopping. Journal of Business Ethics, 39(1-2), 43-50. https://doi.org/10.1023/A:1016323815802

Goodman Report. (2012). An e-retailing research report commissioned by Goodman Group. Retrieved 15 September 2015 from https://www.prnewswire.com/newsreleases/goodman-report-sees-significant-logistics-opportunity-from-the-rapidglobal-growth-in-e-retailing-152533695.html

Gummerus, J., Liljander, V., Pura, M., \& van Riel, A. (2004). Customer loyalty to contentbased web sites: The case of an online health-care service. Journal of Services Marketing, 18(3), 175-186. https://doi.org/10.1108/08876040410536486 
Ha, H.Y., Janda, S., \& Muthaly, S. (2010). Development of brand equity: Evaluation of four alternative models. The Service Industries Journal, 30(6), 911-928. https://doi.org/10.1080/02642060802320253

Hair Jr., J.F., Hult, G.T.M., Ringle, C., \& Sarstedt, M. (2016). A primer on partial least squares structural equation modeling (PLS-SEM). Thousand Oaks, California: Sage Publications.

Harris, L.C., \& Goode, M.M. (2004). The four levels of loyalty and the pivotal role of trust: A study of online service dynamics. Journal of Retailing, 80(2), 139-158. https://doi.org/10.1016/j.jretai.2004.04.002

Hartman, K.B., \& Spiro, R.L. (2005). Recapturing store image in customer-based store equity: A construct conceptualization. Journal of Business Research, 58(8), 1112-1120. https://doi.org/10.1016/j.jbusres.2004.01.008

Hasan, B. (2016). Perceived irritation in online shopping: The impact of website design characteristics. Computers in Human Behavior, 54, 224-230. https://doi.org/10. 1016/j.chb.2015.07.056

He, H., \& Li, Y. (2010). Key service drivers for high-tech service brand equity: The mediating role of overall service quality and perceived value. Journal of Marketing Management, 27(1-2), 77-99. https://doi.org/10.1080/0267257X.2010.495276

Hilton, G. (2002). We must show as well as tell in this new media world. Marketing, 15.

Hoffman, D.L., Novak, T.P., \& Peralta, M. (1999). Building consumer trust online. Communications of the ACM, 42(4), 80-85. https://doi.org/10.1145/299157. 299175

Hong, I.B., \& Cho, H. (2011). The impact of consumer trust on attitudinal loyalty and purchase intentions in B2C e-marketplaces: Intermediary trust vs. seller trust. International Journal of Information Management, 31(5), 469-479. https://doi. org/10.1016/j.ijinfomgt.2011.02.001

Hongyoun Hahn, K., \& Kim, J. (2009). The effect of offline brand trust and perceived internet confidence on online shopping intention in the integrated multi-channel context. International Journal of Retail \& Distribution Management, 37(2), 126141. https://doi.org/10.1108/09590550910934272

Iglesias, O., Markovic, S., \& Rialp, J. (2018). How does sensory brand experience influence brand equity? Considering the roles of customer satisfaction, customer affective commitment, and employee empathy. Journal of Business Research. https://doi. org/10.1016/j.jbusres.2018.05.043

Jain, N.K., Gajjar, H., Shah, B.J., \& Sadh, A. (2017). E-fulfillment dimensions and its influence on customers in e-tailing: A critical review. Asia Pacific Journal of Marketing and Logistics, 29(2), 347-369. https://doi.org/10.1108/ APJML-11-2015-0167

Jin, B., \& Park, J.Y. (2006). The moderating effect of online purchase experience on the evaluation of online store attributes and the subsequent impact on market response outcomes. Advances in Consumer Research, 33, 303.

Kassim, N., \& Abdullah, A. N. (2010). The effect of perceived service quality dimensions on customer satisfaction, trust, and loyalty in e-commerce settings: A cross cultural analysis. Asia Pacific Journal of Marketing and Logistics, 22(3), 351371. https://doi.org/10.1108/13555851011062269 
Kao, T.W.D., \& Lin, W.T. (2016). The relationship between perceived e-service quality and brand equity: A simultaneous equations system approach. Computers in Human Behavior, 57, 208-218. https://doi.org/10.1016/j.chb.2015.12.006

Keller, K.L. (2016). Reflections on customer-based brand equity: Perspectives, progress, and priorities. AMS Review, 6(1-2), 1-16. https://doi.org/10.1007/s13162-0160078-Z

Kim, C., Zhao, W., \& Yang, K.H. (2008). An empirical study on the integrated framework of e-CRM in online shopping: Evaluating the relationships among perceived value, satisfaction, and trust based on customers' perspectives. Journal of Electronic Commerce in Organizations (JECO), 6(3), 1-19. https://doi.org/10.4018/ jeco.2008070101

Kim, J., Jin, B., \& Swinney, J.L. (2009). The role of retail quality, e-satisfaction and e-trust in online loyalty development process. Journal of Retailing and Consumer Services, 16(4), 239-247. https://doi.org/10.1016/j.jretconser.2008.11.019

Kim, J., Sharma, S., \& Setzekorn, K. (2002). A framework for building brand equity online for pure-play B2C retailers and services. International Journal on Media Management, 4(2), 123-133. https://doi.org/10.1080/14241270209389989

Kim, S., \& Stoel, L. (2004). Apparel retailers: Website quality dimensions and satisfaction. Journal of Retailing and Consumer Services, 11(2), 109-117. https://doi.org/ 10.1016/S0969-6989(03)00010-9

Kim, Y., \& Peterson, R.A. (2017). A meta-analysis of online trust relationships in e-commerce. Journal of Interactive Marketing, 38, 44-54. https://doi.org/ 10.1016/j.intmar.2017.01.001

Kotha, S., Rajgopal, S., \& Rindova, V. (2001). Reputation building and performance: An empirical analysis of the top-50 pure internet firms. European Management Journal, 19(6), 571-586. https://doi.org/10.1016/S0263-2373(01)00083-4

Koufteros, X., Droge, C., Heim, G., Massad, N., \& Vickery, S.K. (2014). Encounter satisfaction in e-tailing: Are the relationships of order fulfillment service quality with its antecedents and consequences moderated by historical satisfaction? Decision Sciences, 45(1), 5-48. https://doi.org/10.1111/deci.12056

Lee, M.K., \& Turban, E. (2001). A trust model for consumer internet shopping. International Journal of Electronic Commerce, 6(1), 75-91. https://doi.org/10.1080/10864415 .2001 .11044227

Liao, Z., \& Cheung, M.T. (2002). Internet-based e-banking and consumer attitudes: An empirical study. Information \& Management, 39(4), 283-295. https://doi. org/10.1016/S0378-7206(01)00097-0

Liu, C., \& Arnett, K.P. (2000). Exploring the factors associated with website success in the context of electronic commerce. Information \& Management, 38(1), 23-33. https://doi.org/10.1016/S0378-7206(00)00049-5

Liu, X., He, M., Gao, F., \& Xie, P. (2008). An empirical study of online shopping customer satisfaction in China: A holistic perspective. International Journal of Retail \& Distribution Management, 36(11), 919-940. https://doi.org/10. 1108/09590550810911683 
Lin, H.H., \& Wang, Y.S. (2006). An examination of the determinants of customer loyalty in mobile commerce contexts. Information \& Management, 43(3), 271-282. https://doi.org/10.1016/j.im.2005.08.001

Loiacono, E.T., Watson, R.T., \& Goodhue, D.L. (2002). WebQual: A measure of website quality. Marketing Theory and Applications, 13(3), 432-438.

Londoño, J.C., Elms, J., \& Davies, K. (2016). Conceptualising and measuring consumerbased brand-retailer-channel equity. Journal of Retailing and Consumer Services, 29, 70-81. https://doi.org/10.1016/j.jretconser.2015.11.004

López-Miguens, M.J., \& Vázquez, E.G. (2017). An integral model of e-loyalty from the consumer's perspective. Computers in Human Behavior, 72, 397-411. https://doi. org/10.1016/j.chb.2017.02.003

Loureiro, S.M.C. (2013). The effect of perceived benefits, trust, quality, brand awareness/ associations and brand loyalty on internet banking brand equity. International Journal of Electronic Commerce Studies, 2, 139-158. https://doi.org/10.7903/ ijecs. 1000

Mayer, R.C., Davis, J.H., \& Schoorman, F.D. (1995). An integrative model of organizational trust. Academy of Management Review, 20(3), 709-734. https://doi.org/10.5465/ amr.1995.9508080335

Mazur, L. (2001). Brand guardians must be alert to threat of the net. Marketing, 24.

McKinney, V., Yoon, K., \& Zahedi, F.M. (2002). The measurement of web-customer satisfaction: An expectation and disconfirmation approach. Information Systems Research, 13(3), 296-315. https://doi.org/10.1287/isre.13.3.296.76

McKnight, D.H., Choudhury, V., \& Kacmar, C. (2002). Developing and validating trust measures for e-commerce: An integrative typology. Information Systems Research, 13(3), 334-359. https://doi.org/10.1287/isre.13.3.334.81

Mentzer, J.T., Gomes, R., \& Krapfel Jr., R.E. (1989). Physical distribution service: A fundamental marketing concept? Journal of the Academy of Marketing Science, 17(1), 53-62. https://doi.org/10.1007/BF02726354

Meyers, L.S., Gamst, G., \& Guarino, A.J. (2016). Applied multivariate research: Design and interpretation. Thousand Oaks, California: Sage Publications.

Morgan, R.M., \& Hunt, S.D. (1994). The commitment-trust theory of relationship marketing. The Journal of Marketing, 58(3), 20-38. https://doi.org/10.2307/1252308

Nguyen, D.H., de Leeuw, S., \& Dullaert, W.E. (2018). Consumer behaviour and order fulfilment in online retailing: A systematic review. International Journal of Management Reviews, 20(2), 255-276. https://doi.org/10.1111/ijmr.12129

Oliveira, T., Alhinho, M., Rita, P., \& Dhillon, G. (2017). Modelling and testing consumer trust dimensions in e-commerce. Computers in Human Behavior, 71, 153-164. https://doi.org/10.1016/j.chb.2017.01.050

Page, C., \& Lepkowska-White, E. (2002). Web equity: A framework for building consumer value in online companies. Journal of Consumer Marketing, 19(3), 231-248. https://doi.org/10.1108/07363760210426058

Pappu, R., \& Quester, P. (2006). Does customer satisfaction lead to improved brand equity? An empirical examination of two categories of retail brands. Journal of Product \& Brand Management, 15(1), 4-14. https://doi.org/10.1108/10610420610650837 
Park, C.H., \& Kim, Y.G.(2003). Identifying key factors affecting consumer purchase behavior in an online shopping context. International Journal of Retail \& Distribution Management, 31(1), 16-29. https://doi.org/10.1108/09590550310457818

Pavlou, P.A., \& Gefen, D. (2005). Psychological contract violation in online marketplaces: Antecedents, consequences, and moderating role. Information Systems Research, 16(4), 372-399. https://doi.org/10.1287/isre.1050.0065

Pavlou, P.A., Liang, H., \& Xue, Y. (2007). Understanding and mitigating uncertainty in online exchange relationships: A principal-agent perspective. MIS Quarterly, 31(1), 105-136. https://doi.org/10.2307/25148783

Piercy, N. (2014). Online service quality: Content and process of analysis. Journal of Marketing Management, 30(7-8), 747-785. https://doi.org/10.1080/026725 7X.2013.839571

Porter, M.E. (1980). Competitive strategy: Techniques for analyzing industries and competitors. New York: The Free Press.

Preacher, K.J., \& Hayes, A.F. (2004). SPSS and SAS procedures for estimating indirect effects in simple mediation models. Behavior Research Methods, Instruments, \& Computers, 36(4), 717-731. https://doi.org/10.3758/BF03206553

Reichheld, F.F., Markey Jr., R.G., \& Hopton, C. (2000). E-customer loyalty-applying the traditional rules of business for online success. European Business Journal, 12(4), 173.

Ribbink, D., van Riel, A.C., Liljander, V., \& Streukens, S. (2004). Comfort your online customer: Quality, trust and loyalty on the internet. Managing Service Quality: An International Journal, 14(6), 446-456. https://doi. org/10.1108/09604520410569784

Rana, A., Bhat, A., \& Rani, L. (2015). A classificatory scheme for antecedents of the sources of online brand equity. Journal of Research in Interactive Marketing, 9(4), 262-298. https://doi.org/10.1108/JRIM-02-2014-0008

Rios, R.E., \& Riquelme, H.E. (2008). Brand equity for online companies. Marketing Intelligence \& Planning, 26(7), 719-742. https://doi.org/10.1108/02634500 810916681

Rios, R.E., \& Riquelme, H.E. (2010). Sources of brand equity for online companies. Journal of Research in Interactive Marketing, 4(3), 214-240. https://doi. org/10.1108/17505931011070587

Rowley, J. (2009). Online branding strategies of UK fashion retailers. Internet Research, 19(3), 348-369. https://doi.org/10.1108/10662240910965397

Santos, J. (2003). E-service quality: A model of virtual service quality dimensions. Managing Service Quality: An International Journal, 13(3), 233-246. https://doi. org/10.1108/09604520310476490

Schultz, D.E. (2003). Brand equity: Both ends of the spectrum. Interactive Marketing, 5(1), 5-6. https://doi.org/10.1057/palgrave.im.4340212

Sealey, P. (1999). How e-commerce will trump brand management. Harvard Business Review, 77, 171-176.

Shankar, V., Urban, G.L., \& Sultan, F. (2002). Online trust: A stakeholder perspective, concepts, implications, and future directions. The Journal of Strategic Information Systems, 11(3-4), 325-344. https://doi.org/10.1016/S0963-8687(02)00022-7 
Shi, S., Mu, R., Lin, L., Chen, Y., Kou, G., \& Chen, X.J. (2018). The impact of perceived online service quality on swift guanxi: Implications for customer repurchase intention. Internet Research, 28(2), 432-455. https://doi.org/10.1108/IntR-122016-0389

Singh, J., \& Sirdeshmukh, D. (2000). Agency and trust mechanisms in consumer satisfaction and loyalty judgments. Journal of the Academy of Marketing Science, 28(1), 150-167. https://doi.org/10.1177/0092070300281014

Subramanian, N., Gunasekaran, A., Yu, J., Cheng, J., \& Ning, K. (2014). Customer satisfaction and competitiveness in the Chinese e-retailing: Structural equation modeling (SEM) approach to identify the role of quality factors. Expert Systems with Applications, 41(1), 69-80. https://doi.org/10.1016/j.eswa.2013.07.012

Sun, P., Cárdenas, D.A., \& Harrill, R. (2016). Chinese customers' evaluation of travel website quality: A decision-tree analysis. Journal of Hospitality Marketing \& Management, 25(4), 476-497. https://doi.org/10.1080/19368623.2015.1037977

Swoboda, B., Weindel, J., \& Hälsig, F. (2016). Predictors and effects of retail brand equity: A cross-sectoral analysis. Journal of Retailing and Consumer Services, 31, 265276. https://doi.org/10.1016/j.jretconser.2016.04.007

Szymanski, D.M., \& Hise, R.T. (2000). E-satisfaction: An initial examination. Journal of Retailing, 76(3), 309-322. https://doi.org/10.1016/S0022-4359(00)00035-X

Tabachnick, B.G., \& Fidell, L.S. (1983). Cleaning up your act: Screening data prior to analysis. In B.G. Tabachnick \& L.S. Fidell (Eds.), Using multivariate statistics (pp. 68-81). New York: Harper.

Tamimi, N., Rajan, M., \& Sebastianelli, R. (2003). The state of online retailing. Internet Research, 13(3), 146-155. https://doi.org/10.1108/10662240310478178

Tongco, M.D.C. (2007). Purposive sampling as a tool for informant selection. Ethnobotany Research and Applications, 5, 147-158. https://doi.org/10.17348/era.5.0.147-158

Winch, G., \& Joyce, P. (2006). Exploring the dynamics of building, and losing, consumer trust in $\mathrm{B} 2 \mathrm{C}$ e-business. International Journal of Retail \& Distribution Management, 34(7), 541-555. https://doi.org/10.1108/09590550610673617

Wolfinbarger, M., \& Gilly, M.C. (2003). ETailQ: Dimensionalizing, measuring and predicting retail quality. Journal of Retailing, 79(3), 183-198. https://doi. org/10.1016/S0022-4359(03)00034-4

Yadav, M.S., \& Pavlou, P.A. (2014). Marketing in computer-mediated environments: Research synthesis and new directions. Journal of Marketing, 78(1), 20-40. https://doi.org/10.1509/jm.12.0020

Yoo, B., \& Donthu, N. (2001). Developing a scale to measure the perceived quality of an Internet shopping site (SITEQUAL). Quarterly Journal of Electronic Commerce, 2(1), 31-45.

Yoo, B., Donthu, N., \& Lee, S. (2000). An examination of selected marketing mix elements and brand equity. Journal of the Academy of Marketing Science, 28(2), 195-211. https://doi.org/10.1177/0092070300282002

Zeithaml, V.A., Parasuraman, A., \& Malhotra, A. (2002). Service quality delivery through web sites: A critical review of extant knowledge. Journal of the Academy of Marketing Science, 30(4), 362. https://doi.org/10.1177/009207002236911 